\title{
Succinate dehydrogenase inhibitor (SDHI) fungicide resistance prevention strategy
}

\author{
A.H. McKay ${ }^{1}$, G.C. Hagerty ${ }^{2}$, G.B. Follas 3 , M.S. Moore ${ }^{4}$, M.S. Christie ${ }^{5}$ and \\ R.M. Beresford ${ }^{1}$ \\ ${ }^{1}$ The New Zealand Institute for Plant \& Food Research Ltd, Mt Albert Research Centre, \\ Private Bag 92169, Auckland 1142, New Zealand \\ ${ }^{2}$ BASF New Zealand Ltd, 1/333 Harewood Rd, Christchurch, New Zealand \\ ${ }^{3}$ Syngenta Crop Protection Ltd., Tower 2, Level 7, 110 Symonds St, Auckland, \\ New Zealand \\ ${ }^{4}$ Bayer CropScience, 91 Treffers Road, Sockburn, Christchurch, New Zealand \\ ${ }^{5}$ DuPont New Zealand Ltd, PO Box 12173, Penrose, Auckland, New Zealand \\ Corresponding author: rberesford@plantandfood.co.nz
}

\begin{abstract}
Succinate dehydrogenase inhibitor (SDHI) fungicides are currently represented in New Zealand by eight active ingredients: bixafen, boscalid, carboxin, fluaxapyroxad, fluopyram, isopyrazam, penthiopyrad and sedaxane. They are either currently registered or undergoing development in New Zealand for use against a range of ascomycete and basiodiomycete pathogens in crops, including cereals, ryegrass seed, apples, pears, grapes, stonefruit, cucurbits and kiwifruit. These fungicides are considered to have medium to high risk of resistance development, and resistance management is recommended by the Fungicide Resistance Action Committee (FRAC) in Europe. Guidelines are presented for use of SDHI fungicides in New Zealand to help avoid or delay the development of resistance in the fungal pathogens that they target.
\end{abstract}

Keywords mode of action, activity group, insensitivity.

\section{INTRODUCTION}

The guidelines presented here are designed to avoid or delay the development of resistance in plant pathogens in New Zealand to fungicides that are in the succinate dehydrogenase inhibitor (SDHI) activity group. The guidelines have been developed by the New Zealand Committee on Pesticide Resistance (NZCPR) (Beresford et al. 2009) in consultation with the New Zealand Association for Animal Health and Crop Protection (AGCARM, www.agcarm.co.nz/). They are based on recommendations from the Fungicide Resistance Action Committee (FRAC) (www.frac.info/frac/index.htm), who base their resistance prevention guidelines on laboratory and field resistance instances to SDHI fungicides worldwide. Guidelines for specific New Zealand crops are similar to FRAC guidelines and take into account aspects of local cropping practices and disease epidemiology considered to be important by the NZCPR. All New Zealand pesticide resistance strategies can be found on the New Zealand Plant Protection Society web site (www.nzpps.org). 


\section{PRODUCT PERSPECTIVE}

SDHI fungicides are derived from a diverse range of chemistry and, depending on the host and pathogen, have protectant, translaminar or systemic activity. They have been given the FRAC activity group code number 7 (NZPPS 2009) and comprise seven chemical groups including phenyl-benzamides and pyridinyl-ethylbenzamides as well as furan-, oxathiin-, thiazole-, pyrazole- and pyridine-carboxamides. Eight active ingredients from four of these chemical classes are currently registered or undergoing development in New Zealand (Table 1). SDHI fungicides specifically inhibit fungal respiration by blocking the ubiquinone-binding sites in the mitochondrial complex II (Avenot \& Michailides 2010). Generation I SDHIs, including carboxin and oxycarboxin, have been used internationally since the late 1960s and are highly effective against basidiomycete pathogens such as rusts or Rhizoctonia sp. The newer generation II SDHIs, such as boscalid, fluxapyroxad, penthiopyrad, isopyrazam and fluopyram, have a spectrum of activity against a broader range of fungal pathogens of various crops (Avenot \& Michailides 2010). Generation II SDHIs are intended for use in integrated disease management programmes, or as mixing or alternation partners to prevent fungicide resistance. Fungicides from this class are effective against various diseases of cereals, grape, stonefruit, strawberry, kiwifruit, apple and cucurbit (Table 2).

\section{CURRENT STATUS OF SDHI RESISTANCE}

The FRAC website lists the SDHI fungicides as medium to high risk of selecting for resistance in fungal pathogen populations based primarily on single-site mutations of the gene encoding the target succinate dehydrogenase enzyme. Reported resistance has been limited to the generation I fungicide carboxin as well as to the generation II SDHI boscalid. Table 3 summarises the reported resistance determined through laboratory studies and Table 4 summarises instances of field resistance.

Higher frequencies of boscalid resistant isolates of Alternaria alternata were recovered from pistachio orchards that had been treated with repeated applications of the pre-mixed fungicide Pristine ${ }^{\circledR}$ (boscalid + pyraclostrobin) (Avenot \& Michailides 2010). High frequencies of boscalid resistance were also reported in isolates of the gummy stem blight pathogen, Didymella bryoniae, in watermelon field plots treated with boscalid. Repeated applications of boscalid also led to the recovery of resistant isolates of Botrytis cinerea from vineyards across Europe (Stammler et al. 2007) and boscalid-resistant isolates of Corynespora cassiicola in cucumber greenhouses in Japan (Miyamoto et al. 2009).

In laboratory screenings, all A. alternata isolates that were resistant to boscalid were found to be resistant also to penthiopyrad (pyrazole) and fluopyram (benzamide), two generation II SDHI fungicides that have shown broad-spectrum activity against filamentous fungi. Similarly, boscalid-resistant isolates of D. bryoniae were also insensitive to penthiopyrad (Avenot \& Michailides 2010).

Table 1 Succinate dehydrogenase inhibitor fungicides marketed or in development in New Zealand.

\begin{tabular}{lll}
\hline Chemical group & Common name & Trade name \\
\hline Oxathiin-carboxamide & carboxin & Vitaflo ${ }^{\circledR} 200$ \\
\hline Pyridine-carboxamide & boscalid & Pristine $^{\circledR}$, Collis $^{\circledR}$ \\
\hline Pyrazole-carboxamide & bixafen & In development \\
& fluxapyroxad & In development \\
& isopyrazam & Seguris Flexi \\
& penthiopyrad & In development \\
& sedaxane & In development \\
\hline Pyridinyl-ethyl-benzamide & fluopyram & In development \\
\hline
\end{tabular}


Table 2 Pathogens and crops targeted by succinate dehydrogenase inhibitor fungicides in New Zealand.

\begin{tabular}{lll}
\hline Pathogen & Disease & Crop \\
\hline Puccinia hordei & Brown rust & Barley \\
Pyrenophora teres & Net blotch & \\
Ramularia collo-cygni & Ramularia leaf and awn spot & \\
Rhynchosporium secalis & Scald & \\
\hline Puccinia recondita & Leaf rust & Wheat \\
Puccinia striiformis & Stripe rust & \\
Mycosphaerella graminicola & Speckled leaf blotch & \\
\hline Venturia inaequalis & Black spot (scab) & Apple \\
Podoshaera leucotricha & Powdery mildew & \\
Botrytis cinerea & Dry eye rot & \\
\hline Venturia pyrina & Black spot (scab) & Pear \\
\hline Puccinia graminis & Stem rust & Ryegrass seed crops \\
Puccinia coronata & Crown rust & \\
\hline Botrytis cinerea & Botrytis bunch rot (grey mould) & Grapes \\
Erysiphe necator & Powdery mildew & \\
\hline Monilinia fructicola & Blossom blight/brown rot & Stonefruit \\
Botrytis cinerea & Grey mould & \\
\hline Didymella bryoniae & Gummy stem blight & Squash and pumpkin \\
Sphaerotheca fuliginea, syn. Podosphaera & Powdery mildew & \\
xanthii and Erysiphe cichoracearum & & \\
Sclerotinia sclerotiorum & Sclerotinia blossom and fruit rot & Kiwifruit \\
\hline
\end{tabular}

Table 3 Reported laboratory resistance to the succinate dehydrogenase inhibitor fungicide, carboxin.

\begin{tabular}{ll}
\hline Organism & Reference \\
\hline Ustilago maydis & Keon et al. 1991; Broomfield \& Hargreaves 1992 \\
Mycosphaerella graminicola & Skinner et al. 1998 \\
Pleurotus ostreatus & Honda et al. 2000 \\
Aspergillus oryzae & Shima et al. 2011 \\
Coprinus cinereus & Ito et al. 2004 \\
\hline
\end{tabular}

Table 4 Reported field resistance to the succinate dehydrogenase inhibitor fungicides carboxin and boscalid.

\begin{tabular}{|c|c|c|}
\hline Crop and location & Disease & Reference \\
\hline Kiwifruit, grape, strawberry, apple (Greece) & $\begin{array}{l}\text { Botrytis fruit rot } \\
\text { (Botrytis cinerea) }\end{array}$ & $\begin{array}{l}\text { Bardas et al. 2010; Stammler } \\
\text { et al. 2007; Kim \& Xiao } 2009\end{array}$ \\
\hline Pistachio (California, USA) & $\begin{array}{l}\text { Alternaria blight } \\
\text { (Alternaria alternata) }\end{array}$ & Avenot \& Michailides 2007 \\
\hline Cucumber (Japan) & $\begin{array}{l}\text { Corynespora leaf spot } \\
\text { (Corynespora cassiicola) }\end{array}$ & Miyamoto et al. 2009 \\
\hline Watermelon (Georgia, USA) & $\begin{array}{l}\text { Gummy stem blight } \\
\text { (Didymella bryoniae) }\end{array}$ & Stevenson et al. 2008 \\
\hline Cucurbits (New York and Georgia, USA) & $\begin{array}{l}\text { Cucurbit powdery mildew } \\
\text { (Podosphaera xanthii) }\end{array}$ & $\begin{array}{l}\text { McGrath } 2008 \\
\text { Miazzi \& McGrath } 2008\end{array}$ \\
\hline
\end{tabular}




\section{RESISTANCE PREVENTION STRATEGY General guidelines}

All SDHI fungicide active ingredients (Table 1) are in the same cross-resistance group. Effective disease management is essential to delay the build-up of resistant pathogen strains and should combine use of appropriate fungicides with cultural control methods. Apply products containing SDHI fungicides at effective rates, intervals and crop stages according to manufacturers' recommendations. The number of applications of products containing SDHI fungicides must be limited according to the guidelines below for specific crops. Maximum numbers of SDHI applications apply to the crop, not to individual target diseases. Where mixtures (tank mix or co-formulation) or alternation are required, the partner fungicide should be capable of providing satisfactory control of the target disease when used alone, and must be from a different activity group (i.e. not Group 7). Refer to manufacturers' recommendations for rates of partner fungicides. SDHI fungicides should be used preventatively and not curatively, when the amount of disease is low, but disease risk is high. Do not use SDHI fungicides when disease is well established.

\section{Cereals}

Use a maximum of two applications of products containing SDHI fungicide per crop. SDHI fungicides must be applied in mixture with a fungicide of a different group. Do not use SDHI fungicides in repeated applications at reduced rates as this increases the risk of selecting resistance in pathogen populations.

\section{Ryegrass seed crops}

Use a maximum of two applications of products containing SDHI fungicide per crop. SDHI fungicides must be applied either in strict alternation or in mixture.

\section{Squash and pumpkin}

Use a maximum of two applications of products containing SDHI fungicide per crop, preferably in mixture. If used alone, apply SDHI fungicides in strict alternation with effective fungicides from a different activity group.

\section{Stonefruit}

Use a maximum of three applications of products containing SDHI fungicide per season, preferably in mixture. If used alone, apply SDHI fungicides in strict alternation with effective fungicides from a different activity group. If used in mixture, do not make more than two consecutive applications of products containing a SDHI fungicide. Use of SDHI fungicides should be restricted to a single stage of crop development. Use during the flowering period and do not use near harvest time.

\section{Grape}

Use a maximum of two applications of products containing SDHI fungicide per season, preferably in mixture. If used alone, apply SDHI fungicides in strict alternation with effective fungicides from a different activity group. When targeted specifically against botrytis bunch rot (grey mould, B. cinerea), the maximum numbers of applications of SDHI fungicides are given in Table 5. These maxima apply to all diseases of grapes and must not be exceeded when targeting powdery mildew (Erysiphe necator).

Table 5 Recommended maximum number of applications per season of products containing succinate dehydrogenase inhibitor (SDHI) fungicides against botrytis bunch rot (grey mould, Botrytis cinerea) in grapes in relation to the total number of applications per season.

\begin{tabular}{lllllc}
\hline Total no. B. cinerea spray applications per season & 1 & 2 & 3 & 4 & 5 or more \\
\hline Maximum number of solo SDHI applications ${ }^{1}$ & 1 & 1 & 1 & 2 & 2 \\
Maximum number of SDHI applications in mixture & 1 & 1 & 2 & 2 & 2 \\
\hline
\end{tabular}

${ }^{1}$ Where two applications of SDHI fungicides are made alone, they must not be consecutive and the alternate fungicide application(s) must be capable of providing effective suppression of $B$. cinerea. 


\section{Apple and pear}

Apply a maximum of three SDHI containing sprays per season. A maximum of four SDHI fungicide applications may be used where 12 or more applications are made per season. SDHI fungicides should preferably be applied in mixture. If used alone, apply SDHI fungicides in strict alternation with effective fungicides from a different activity group. Apply a maximum of two consecutive SDHI fungicide sprays. Under high disease pressure the spray interval should not exceed 7-10 days.

\section{Kiwifruit}

Use a maximum of two SDHI containing fungicides per year over all diseases, preferably in mixture. If used alone, apply SDHI fungicides in strict alternation with fungicides in a different activity group. Use of SDHI fungicides should be restricted to a single stage of crop development. Use during the flowering period and do not use near harvest time.

\section{Other crops}

Use a maximum of two SDHI containing fungicides per year over all diseases, preferably in mixture. If used alone, apply SDHI fungicides in strict alternation with fungicides in a different activity group.

\section{RESISTANCE PREVENTION STRATEGY IMPLEMENTATION}

These resistance prevention and management guidelines should be implemented for all products containing a SDHI fungicide by including a statement on the product label under the heading "Resistance Prevention". This should include the statement "This product contains a "GROUP 7 (SDHI) fungicide that is at risk from resistance development. Do not use in conjunction with other products containing a GROUP 7 (SDHI) fungicide when adhering to the fungicide mixture and alternation guidelines for the specific crops below." The general guidelines and appropriate crop-specific guidelines for Group 7 fungicide applications should then follow.

\section{REFERENCES}

Avenot HF, Michailides TJ 2007. Resistance to boscalid fungicide in Alternaria alternata isolates from pistachio in California. Plant Disease 91: 1345-1350.

Avenot HF, Michailides TJ 2010. Progress in understanding molecular mechanisms and evolution of resistance to succinate dehydrogenase inhibiting (SDHI) fungicides in phytopathogenic fungi. Crop Protection 29:643-651.

Bardas GA, Veloukas T, Koutita O, Karaoglanidis GS 2010. Multiple resistance of Botrytis cinerea from kiwifruit to SDHIs, QoIs and fungicides of other chemical groups. Pest Management Science 66:967-973.

Beresford RM, Follas GB, Hagerty GC, Harrington KC, Martin NA 2009. The New Zealand Committee on Pesticide Resistance (NZCPR). New Zealand Plant Protection 62: 393-394.

Broomfield PLE, Hargreaves JA 1992. A single amino-acid change in the iron-sulphur protein subunit of succinate dehydrogenase confers resistance to carboxin in Ustilago maydis. Current Genetics 22:117-121.

Honda Y, Matsuyama T, Irie T, Watanabe T, Kuwahara M 2000. Carboxin resistance transformation of the Homobasidiomycete fungus Pleurotus ostreatus. Current Genetics 37:209-212.

Ito Y, Muraguchi H, Seshime Y, Oita S, Yanagi SO 2004. Flutolanil and carboxin resistance in Coprinus cinereus conferred by a mutation in the cytochrome b. Molecular Genetics and Genomics 272: 328-335.

Keon JPR, White GA, Hargreaves JA 1991. Isolation, characterization and sequence of a gene conferring resistance to the systemic fungicide carboxin from the maize smut pathogen, Ustilago maydis. Current Genetics 19: 475-481.

Kim YK, Xiao CL 2009. Resistance to pyraclostrobin and boscalid in Botrytis cinerea populations from apple in Washington State. Phytopathology 99: S62 (abstract only). 
McGrath MT 2008. Fungicide sensitivity in Podosphaera xanthii and efficacy for cucurbit powdery mildew in NY USA in 2003-2006. Journal of Plant Pathology 90:S2 (abstract only).

Miazzi M, McGrath MT 2008. Sensitivity of Podosphaera xanthii to registered fungicides and experimentals in GA and NY, USA, in 2007. Journal of Plant Pathology 90: S2 (abstract only)

Miyamoto T, Ishii H, Seko T, Kobori S, Tomita Y 2009. Occurrence of Corynespora cassiicola isolates resistant to boscalid on cucumber in Ibaraki Prefecture, Japan. Plant Pathology 58: 1144-1151.

NZPPS 2009. New Zealand Committee on Pesticide Resistance Mode of Action/ Activity Group Codes for Crop Protection Chemicals. New Zealand Plant Protection Society December 2009. http://ww.nzpps. org/resistance/pdfs/moa_codes.pdf.

Skinner W, Bailey A, Renwick A, Keon J, Gurr S, Hargreaves J 1998. A single amino-acid substitution in the iron-sulphur protein subunit of succinate dehydrogenase determines resistance to carboxin in Mycosphaerella graminicola. Current Genetics 34: 393-398.
Shima Y, Ito Y, Hatabayashi H, Koma A, Yabe $\mathrm{K}$ 2011. Five carboxin-resistant mutants exhibited various responses to carboxin and related fungicides. Bioscience, Biotechnology and Biochemistry 75: 181-184.

Stammler G, Brix HD, Glattli A, Semar M, Schoefl U 2007. Biological properties of the carboximide boscalid including recent studies on its mode of action. Proceedings of the XVI international Plant Protection Congress, Glasgow. Pp. 40-45.

Stevenson KL, Langston DB, Sanders F 2008. Baseline sensitivity and evidence of resistance to boscalid in Didymella bryoniae. Phytopathology 98: S151 (abstract only). 